\title{
Decision Strategies for Soil Water Estimations in Soybean Crops Subjected to No-Tillage and Conventional Systems, in Brazil
}

\author{
Lucieta G. Martorano1, Homero Bergamaschi², \\ Rogério T. de Faria ${ }^{3}$ and Genei A. Dalmago ${ }^{4}$ \\ ${ }^{1}$ Embrapa Amazônia Oriental \\ Travessa Eneas Pinheiro s/n, Belém, PA \\ ${ }^{2} U F R G S$ and $C N P q, P$. Alegre, RS \\ ${ }^{3}$ FCAV-Unesp, Jaboticabal, SP \\ ${ }^{4}$ Embrapa Trigo \\ Passo Fundo, RS \\ Brazil
}

\section{Introduction}

Conservationist practices have been increasingly adopted in Brazil during the last thirty years, especially with the change from the conventional cropping system to the no-tillage system. The latter has been widely spread in several Brazilian regions where the soybean crop takes part in annual crop rotation (Denardin et al., 2005). In the Center-Southern region it reached nearly $80 \%$ of grain producers. Among environmental and economic gains are: increasing crop yield, soil water and carbon stocks increments, reductions of production costs, control of soil erosion, mitigation of carbon emissions and water crop deficit. According to Buarque (2006) sustainable agriculture involves several structural changes and faces social and political resistance. In order to mitigate environmental impacts on food production and ecosystem services, policies should aim to develop more resilient cropping systems and provide sustainable management of natural resources.

Soybean is a commodity of great interest in national and international markets of which Brazil is the second largest producer in the World. Climate variability can severely affect crop yield and reduce total food production. Soybean production has proved to be highly dependent on climate to achieve genetic potential of the cultivars used by farmers. Among climate variables, studies in Rio Grande do Sul State, in Southern Brazil, showed that soybean production was mostly correlated with rainfall. Interannual variability in rainfall has been considered the main cause of fluctuations in grain yields (Bergamaschi et al., 2004) for non-irrigated crops.

Periods of water deficits from January to March are frequent and usually coincide with the summer crop critical period (flowering and grain filling), limiting the yield of soybean in the state (Matzenauer et al., 2003).

Decision support systems, such as DSSAT (Decision Support System for Agrotechnology Transfer) can be very useful for cropping system planning. The models included in that 
software were calibrated for different climate and soil conditions and crop management system and also applied by researchers worldwide (Jones et al., 2003). Different physical and physiological processes are simulated by the DSSAT models, such as photosynthesis, respiration, biomass accumulation and partitioning, phenology, growth of leaves, stems and roots (Hoogenboom, 2000, Hoogenboom et al., 2003 ), and soil water extraction (Faria \& Bowen, 2003). After calibration at a site in the state of Rio Grande do Sul, Brazil, the model CROPGRO-Soybean showed a high performance to simulate grain yield and crop growth and variables of development under the no-tillage cropping system and the conventional system (Martorano, 2007; Martorano et al., 2007; Martorano et al., 2008a; Martorano et al., 2008b; Martorano et al., 2009). DSSAT is frequently updated (v4.5 is on http://www.icasa.net), and currently there is a group of researchers working on the calibration of DSSAT/ CENTURY in order to assist in decision strategies.

This chapter presents experimental results used in the assessment of the performance of the DSSAT models, carried out in a site in Rio Grande do Sul, Brazil. This study aimed at the establishment of scenarios for sustainable agriculture, based on principles of data interoperability and DSSAT users' network tools.

\section{Problems and strategies for soybean crops}

Several factors should be considered when evaluating low carbon agriculture, for example, the land use and agricultural management, the correct crop conduction, the evaluation of edapho-climatic characteristics, ethnic and cultural respect, and the aggregation of goods and services to the society. Some studies on sustainability indicators have pointed out that cropping systems, such as the no-tillage system, reduce environmental impacts, improve productivity and have lower production costs. Global climate projections show that temperature increases in some areas with high temperatures could worsen food production problems. Variation in productivity due to water availability is already a common problem for rain fed crops, which are the majority of crop areas in Brazil.

The Brazilian economy is closely linked to the supply of natural resources, especially water use, in agriculture, hydropower generation, industrial sectors, and other human demands. However, the lack of water management may cause several impacts and serious threats to the human population. It is known that water has plenty sources in many regions of Brazil, but this resource may become scarce if there is no concern regarding its maintenance.

Awareness of appropriate use in different segments of the productive sector is indispensable to enable quantifying the "water footprint" (Hoekstra \& Chapagain, 2007), in these sectors. For agriculture, the concerns have turned toward waste of water, not only in arid regions of the world, but also the waste related to improper use and decisions on when, how and what is the most efficient technology to be applied in irrigated crops, for instance.

Decision support tools, such as DSSAT (Decision Support System for Agrotechnology Transfer), show high potential for decision makers to improve management of soybean crops in Brazil, after calibration of the models. Martorano (2007) and Martorano et al (2008a) showed that the CROPGRO-Soybean model had high performance simulating phenological phases, growth and yield under irrigated condition, both in conventional tillage and no tillage. DSSAT models can be a suitable tool to assess the effects of tillage on soil carbon in order to mitigate carbon emissions to the atmosphere (Martorano et al, 2008b). The model can simulate realistic 
scenarios for decision-makers (farmers, managers, agricultural technicians and government), as well as to identify crops problem for scientists defining research priorities.

\section{Material and methodology}

An example of research on soil water status is presented based on a field experiment. To evaluate soil-plant-atmosphere processes associated with soil management on the express condition of water, an experiment was conducted in the cropping season of 2003/04 with soybeans (cv. Fepagro RS10, long cycle), at the Experimental Station of the Federal University of Rio Grande do Sul State (EEA/UFRGS), in Eldorado do Sul, Brazil (30 05'27"S; 51. 40'18" W, altitude 46m). The experiment was sown on 2003, Nov 20 in a typical dystrophic red clay soil, with plots conducted under no-tillage (NT) and conventional tillage $(\mathrm{CT})$, irrigated (I) and not irrigated (NI).

Crop was sown $0.40 \mathrm{~m}$ between rows, with an average population of 300,000 plants ha-1. An automatic meteorological station recorded weather variables and tensiometers (mercury- $\mathrm{Hg}$ column) measured daily soil water matric potential. Weekly assessment on plant growth and development were taken (Fig. 1). Leaf area index (LAI) and dry biomass (leaves, stems, pods and seeds) were determined weekly. Model input included minimum and maximum air temperature $\left({ }^{\circ} \mathrm{C}\right)$, precipitation $(\mathrm{mm})$ and solar radiation $\left(\mathrm{MJ} \mathrm{m}^{-2}\right)$. Soil inputs included soil classes, soil physical-hydraulic and chemical properties, in addition to crop management information (weed control, variety, planting date and irrigation).

Irrigation was applied when soil matric potential reached $-60 \mathrm{kPa}$, as measured by tensiometers installed in irrigated no-tillage plots (NIT). The crop water use was monitored by a weighing lysimeter cultivated with soybean under conventional tillage. Each management system contained two batteries with tensiometers placed at depths $(\mathrm{m})$ of $0.075,0.15,0.30,0.45,0.60,0.75,0.90$ and $1.05 \mathrm{~m}$ and one with the same depths in addition to a tensiometer at $1.20 \mathrm{~m}$. Readings were made every day, around 9 p.m. (local time).
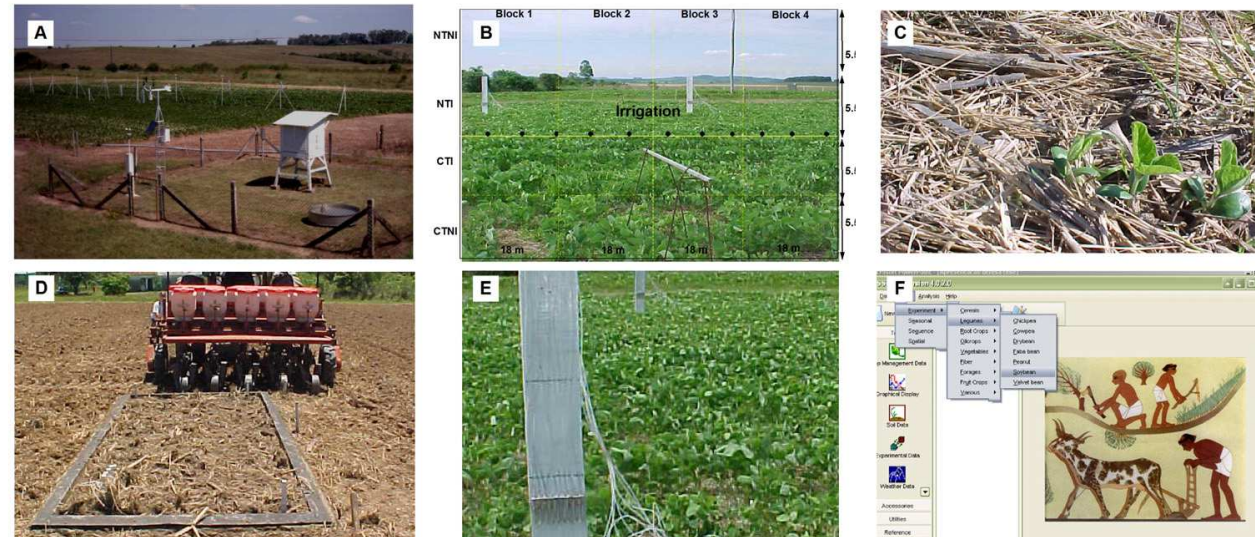

Fig. 1. Meteorological station (A), experimental design (B), soybean in no-tillage system (C), lysimeter (D), batteries with tensiometers (E) in experimental area at the EEA / UFRGS, 2003/04, in Rio Grande do Sul State, Brazil, and layout of software DSSAT initial page (F). 
With matric potential values, the corresponding soil moisture was calculated using the soil retention curves obtained experimentally by Dalmago (2004) for no-tillage and conventional tillage plots. The program of Dourado Neto et al. (2005) was used to calculate the volumetric water content (Soil Water Retention Curve-SWRC, v.1.0), using Equation 1, Van Genuchten (1980):

$$
\theta v=\theta r+\frac{(\theta s-\theta r)}{\left[(1+\alpha \Psi m)^{n}\right]^{m}}
$$

where the volumetric water content $\left(\mathrm{cm}^{3} \mathrm{~cm}^{-3}\right)$ is represented by the $\theta \mathrm{v}$ and humidity and residual saturation $\theta \mathrm{r}$ and $\theta \mathrm{s}$, respectively. The matric potential of soil water $(\mathrm{kPa})$ is represented by $\Psi \mathrm{m}$ and coefficients (dimensionless) by the letters $\alpha, \mathrm{n}$ and $\mathrm{m}$.

In Decision Support System for Agrotechnology Transfer was considered an experimental data of soil, climate and specifications of soil management. The model selected for the legume was CROPGRO Soybean. In this chapter, attention turned to the evaluation of model performance to simulate soil water content. CROPGRO-Soybean was calibrated, using genetic coefficients for the cultivar Fepagro RS-10, as described by Martorano (2007) and Martorano et al (2008a). The methodology of Willmott et al. (1985) recommended the use of RMSE (root mean square error) and D-index (index of agreement), but suggested that RMSE is the "best" measure as it summarizes the mean difference in the units of observed and predicted values (Martin et al., 2007). The RMSE indicates the bias produced by the model, i.e., deviation of the actual slope from the 1:1 line while it also may be seen as a precision measure, as it compares the bias of model predicted values with the random variation that may occur. The D-index is a descriptive (both relative and bounded) measure, and can be applied to make crosscomparisons between observed and simulated data (Loague \& Green, 1991) by equation 2 and 3.

$$
D=1-\left[\frac{\sum_{i-1}^{N}(P i-O i)^{2}}{\sum_{i-1}^{N}\left(\left|P^{\prime} i\right|+\left|O^{\prime} i\right|\right)^{2}}\right]
$$

where $\mathrm{N}$ is the total of observations, $\mathrm{Pi}$ and $\mathrm{Oi}$ are respectively predicted and observed values , $\mathrm{P}^{\prime} \mathrm{i}$ refers to the absolute difference between $\mathrm{Pi}$ and the average of predicted variable $\mathrm{P}$, and $\mathrm{O}^{\prime} \mathrm{i}$ is the difference between the observed value $\mathrm{Oi}$ and the average of observed variable O. The closer to unity is the D-index (Willmott et al., 1985), the higher the index of agreement between observed data and simulated value by the model is. Also, the observed data were compared with those simulated with the mean square error (RMSE), using equation 3 .

$$
R M S E=\sqrt{\frac{\sum_{i-1}^{N}(P i-O i)^{2}}{N}} X \frac{100}{M}
$$

where Pi and Oi are the values of the variables simulated by the model and observed in the field, corresponding to the evaluation interval. The RSME expresses the relative difference 
(\%) between observed and simulated by CROPGRO-Soybean. It is considered highly accurate when the RMSE is less than $10 \%$, good precision between $10 \%$ and $20 \%$, and between $20 \%$ and $30 \%$, which depending on the boundary condition may be acceptable. The model showed low accuracy when error is above $30 \%$.

In this chapter, attention is given to evaluating the model performance for simulating the soil water content. The mean square error (RMSE) was used to expresses the relative difference (\%) between the observed data and estimations by CROPGRO-Soybean, as described by Martorano (2007) and Martorano et al (2008a).

According to data from soil water content and grain yield was applied analysis of variance and means were compared using the Tukey test at 5\% significance level.

\section{Results and discussion}

Evaluating the meteorological information during the soybean cycle (cv. Fepagro RS-10) showed that solar radiation ranged between 8.8 and $27.9 \mathrm{MJ} \mathrm{m}^{-2}$ day-1 $^{-1}$ (Fig. 2), and the average of $20.7 \mathrm{MJ} \mathrm{m}^{-2} \mathrm{day}^{-1}$, corroborate with the climate average for the period in the region which is about $20 \mathrm{MJ} \mathrm{m}^{-2}$ day $^{-1}$ (Bergamaschi et al., 2003). There were two solar radiation peaks; one in January, the first ten-day period of $\left(\mathrm{J}_{1}\right)$, the order of $27 \mathrm{MJ} \mathrm{m}^{-2}$ day- $^{-1}$, and another in March, the second ten-day period $\left(\mathrm{M}_{2}\right)$ close to $25 \mathrm{MJ} \mathrm{m}^{-2}$ days $^{-1}$. These values corroborate with those presented by Cargnelutti Filho et al. (2004), which indicate that in Rio Grande do Sul, the highest averages of solar radiation for 10-day-periods occur during December and January. Regarding the total rainfall, $663.4 \mathrm{~mm}$ were computed during the soybean cycle, with two moments of rain shortage of supply.

As showed in Figure 2, it was observed that in the three first ten-day periods, the total amount of water in the 2003/04 agricultural year was above the climatological normal. In November, the third ten-day period, and in December the first ten-day period, rainfall amounted around $60 \mathrm{~mm}$ and the second ten-day period in December was close to $140 \mathrm{~mm}$, exceeding the normal rainfall value $(100 \mathrm{~mm})$ observed in time series. In December the third ten-day period and in January the first ten-day period showed less rain supply, making it the first moment of water scarcity.

According to Table 1 values, when the crop was at early flowering $\left(R_{1}\right)$, the air temperature was higher but remained below $35^{\circ} \mathrm{C}$ and the minimum was above $10^{\circ} \mathrm{C}$. At the end of the soybean cycle (cv. Fepagro RS-10), there were 1945.1 accumulated degree days (ADD). Meteorological conditions at the experimental site for main phenological stages of soybean crop (Table 1), according to Fehr \& Caviness (1977).

In some crops, changes in phenological stages depend basically on temperature. For soybean crops, high air temperature during the growth stage reduce time for the flowering phase (Major et al., 1975). Under tropical and subtropical conditions, low temperatures limit severely plant growth, that have photosynthetic capacity reduced due to the drop of quantum efficiency of Photsystem II as well as reduced activities of Photosystem I. There is also decrease in cycles of synthesis of stromal enzymes in $\mathrm{C}_{3}$ plants (Allen \& Ort, 2001). 
Days after emergency

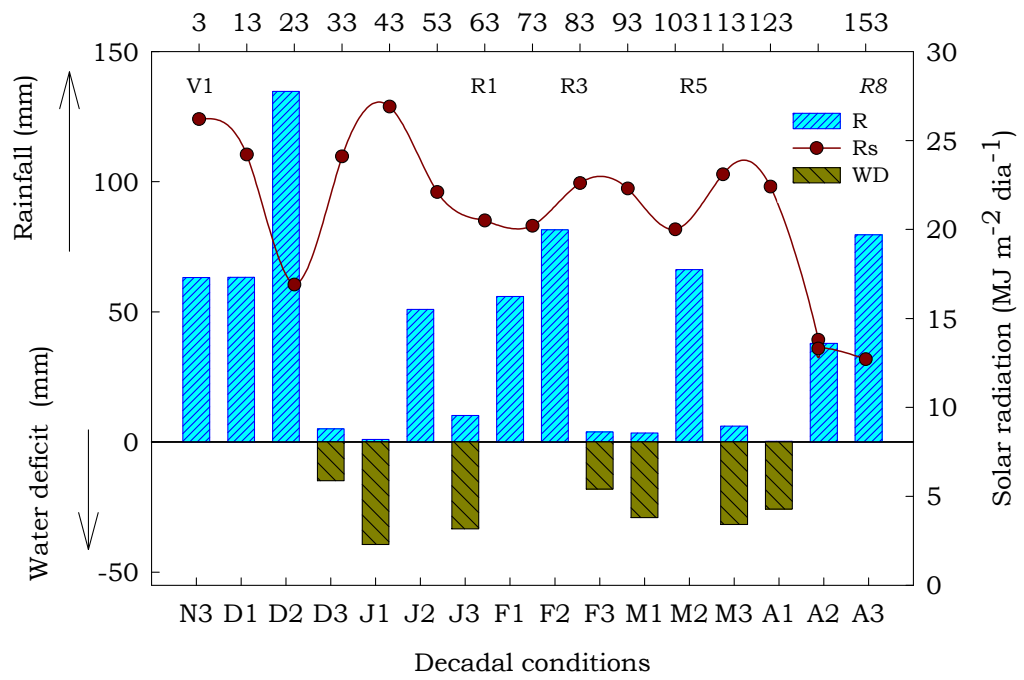

Fig. 2. Rainfall (R), solar radiation (Rs) and water deficit (WD) for ten-day periods during the soybeans cycle in the 2003/04crop year, in Eldorado do Sul, Brazil.

\begin{tabular}{|c|c|c|c|c|c|c|c|c|}
\hline \multirow{2}{*}{ Growth stages } & \multirow{2}{*}{$\begin{array}{c}\text { Rs } \\
\text { MJ m-2 dia-1 }\end{array}$} & \multirow{2}{*}{$\begin{array}{c}\mathrm{R} \\
(\mathrm{mm})\end{array}$} & \multicolumn{3}{|c|}{$\begin{array}{c}\text { Air temperature }\left({ }^{\circ} \mathrm{C}\right) \\
\text { (Average) }\end{array}$} & \multirow{2}{*}{$\begin{array}{c}\text { ADD } \\
\mathrm{Tb}\left(10^{\circ} \mathrm{C}\right) \\
\end{array}$} & \multicolumn{2}{|c|}{$\mathrm{WD}(\mathrm{mm})$} \\
\hline & & & Tmax & Tmin & Tave & & CTNI & NTNI \\
\hline $\mathrm{S}-\mathrm{V}_{11}$ & 22.6 & 328.5 & 28.5 & 16.4 & 22.5 & 789.6 & 101.2 & 93.7 \\
\hline $\mathrm{V}_{11}-\mathrm{R}_{1}$ & 20.1 & 0.0 & 34.3 & 19.4 & 26.9 & 806.5 & 3.1 & 3.5 \\
\hline $\mathrm{R}_{1}-\mathrm{R}_{5}{ }^{*}$ & 21.8 & 141.2 & 29.4 & 16.5 & 22.9 & 1259.6 & 102.1 & 113.4 \\
\hline $\mathrm{R}_{5}^{* *}-\mathrm{R}_{7}$ & 19.2 & 76.1 & 29.3 & 17.1 & 23.2 & 1814.4 & 80.2 & 72.3 \\
\hline$S-\mathbf{R}_{8}$ & 20.6 & 663.4 & 28.6 & 16.3 & 22.5 & 1945.1 & 287.5 & 280.9 \\
\hline
\end{tabular}

Rs (Global solar radiation), R (rainfall), Tmax, Tmin, Tave (maximum, minimum and average air temperature), WD (water deficit). S (sowing), $\mathrm{R}_{1}$ - beginning of flowering, $\mathrm{R}_{5}{ }^{*}$ - first day on $\mathrm{R}_{5}$ period (beginning of grain filling); and $R_{5}{ }^{* *}$ - period between the second day on $R_{5}$ and the first day on $R_{7}$ (physiological maturity) and $\mathrm{R}_{8}$ (complete maturity), ADD (accumulated degree-days calculated in Celsius unit, from seedling emergency on Nov.27.2003 to the end of cycle on Apr.30.2004). Tb is minimum base temperature for soybeans, $10^{\circ} \mathrm{C}$.

Table 1. Meteorological parameters during the soybean cycle (cv. Fepagro RS-10) in different growth stages (Fehr \& Caviness, 1977), in non-irrigated conventional tillage (CTNI) and notillage (NTNI). EEA / UFRGS, Eldorado do Sul, Brazil, 2003/04. 
The results obtained in the field experiments showed that maximum evapotranspiration (ETm) amount during the cycle of soybeans was $681.3 \mathrm{~mm}$, with a daily average of $4.5 \mathrm{~mm}$ day $^{-1}$. In the period between the late vegetative stage $\left(V_{11}\right)$ and early grain filling $\left(R_{5}\right)$, the highest evapotranspiration rates $\left(6\right.$ to $\left.8.0 \mathrm{~mm}^{-1 a y}{ }^{-1}\right)$ were observed between 49 and $93 \mathrm{DAE}$, with degree-days ranging between 789.6 and 1259.6. These rates reflect the condition of the irrigated crop in conventional tillage (lysimeter area) and maximum leaf area index (6.3), obtained in fully flowering $\left(\mathrm{R}_{2}\right)$.

It was observed in Martorano et al (2009) that on Dec 23.2003, the soil under conventional tillage systems without irrigation (CTI) contained $0.236 \mathrm{~cm}^{3} \mathrm{~cm}^{-3}$ of moisture in the superficial layer $(0.075 \mathrm{~m})$, indicating the beginning of drying, which was only observed in no-tillage irrigated (NTI) on Dec.25.2003, when soil water content was $0.270 \mathrm{~cm}^{3} \mathrm{~cm}^{-3}$. These data indicated the anticipation of the soil drying under conventional system compared to no-tillage. On Dec.26.2003, the soil was $0.185 \mathrm{~cm}^{3} \mathrm{~cm}^{-3}$ in CTI and there was disruption of mercury columns of tensiometers on the most superficial layer $(0.075 \mathrm{~m})$, which was only observed in no-tillage on Dec.29, 2003, reinforcing the evidence of higher water storage in the upper layers in no-tillage systems.

In the subsequent depth of $0.15 \mathrm{~m}$, the tensiometers $\mathrm{Hg}$-columns disrupted in plots under conventional system on Dec.28.2003, while in no-tillage this fact occurred only on Jan.03.2004, showing that there is anticipation in soil drying front under conventional systems compared to no-tillage (Fig.3). By analyzing all the soil profile, observed that there was more rapidly advancing drying front in conventional system compared to no-tillage. In this first period of drying, the crop was in its growing period, and monitoring of plant responses to water conditions was focused on the second moment of less rainfall.

The second period of water shortage was from February, coinciding with the flowering and grain filling (from $R_{1}$ to $R_{5}$ stages), considered as critical in terms of water requirement for soybean crops (Berlato \& Fontana, 1999). In this aspect, Martorano et al. (2009) showed the pattern of drying soil, indicating that the matric potential in the conventional system were more negative in relation to the no-tillage system. From 0.45 to $0.90 \mathrm{~m}$ of soil depth in the no-tillage and from 0.30 to $1.05 \mathrm{~m}$ in the conventional system, the soil remained drier than in the rest of the profile, probably due to a greater concentration of roots in these soil layers than in the surface layer, resulting from the tap root system of soybeans (Fig. 4). At $0.30 \mathrm{~m}$ deep, the matric potential in no-tillage was higher than $-0.03 \mathrm{MPa}$, which was less negative than in the conventional system, around $-0.05 \mathrm{MPa}$ (Fig.5).

It is known that less soil moisture may place restrictions on water transfer to the atmosphere, not only influenced by the weather, but also by factors such as the root system, cultivar, management system, phytosanitary conditions and soil characteristics. For the conditions of the experiment, the main limiting factor was the reduction in water supply by rainfall, leading to periods of water deficit. The irrigated water treatment presents a brief discussion of the dynamics of soil water by simulated CROPGRO-Soybean and observed in field experiment showing the performance of the tool to simulate soil drying times. Fig. 6 shows that the moisture in the soil between 0.05 and $0.15 \mathrm{~cm}$ depths had differences management systems, indicating that no-tillage values showed higher humidity compared to conventional tillage irrigated condition, confirming the studies of Dalmago (2004) on the dynamics of drying the soil in these two management systems. 


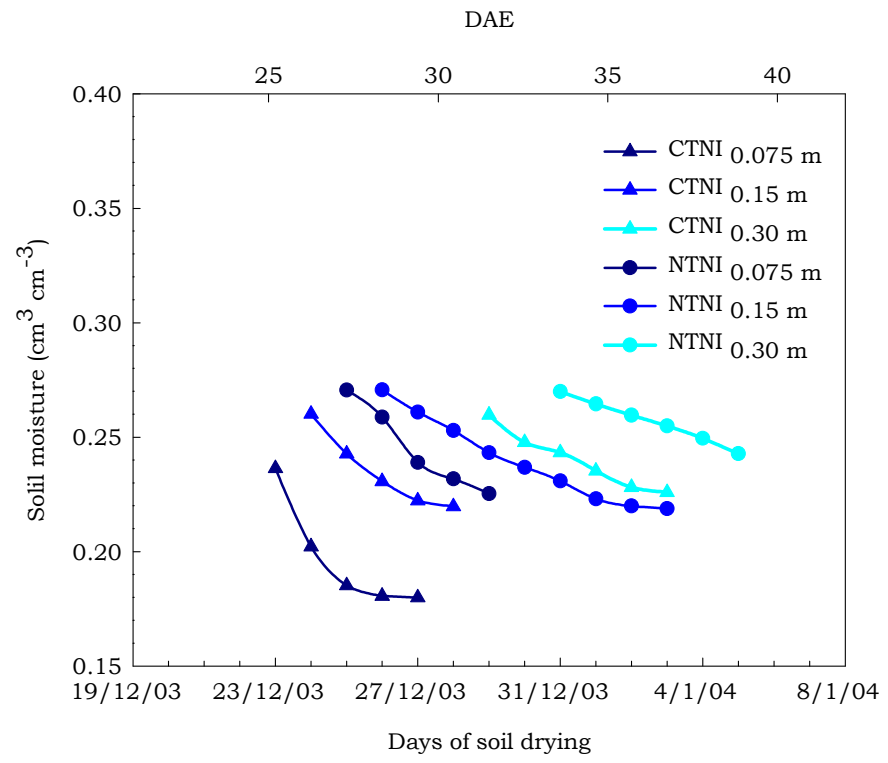

Fig. 3. Soil moisture in functions of days of soil drying and days after soybean plants emergence (DAE) under non-irrigated conventional tillage (CTNI) and no-tillage system (NTNI), in depths between $0.075 \mathrm{~m}$ and $0.30 \mathrm{~m}$. Eldorado do Sul, Brazil, 2003/04, Brazil.

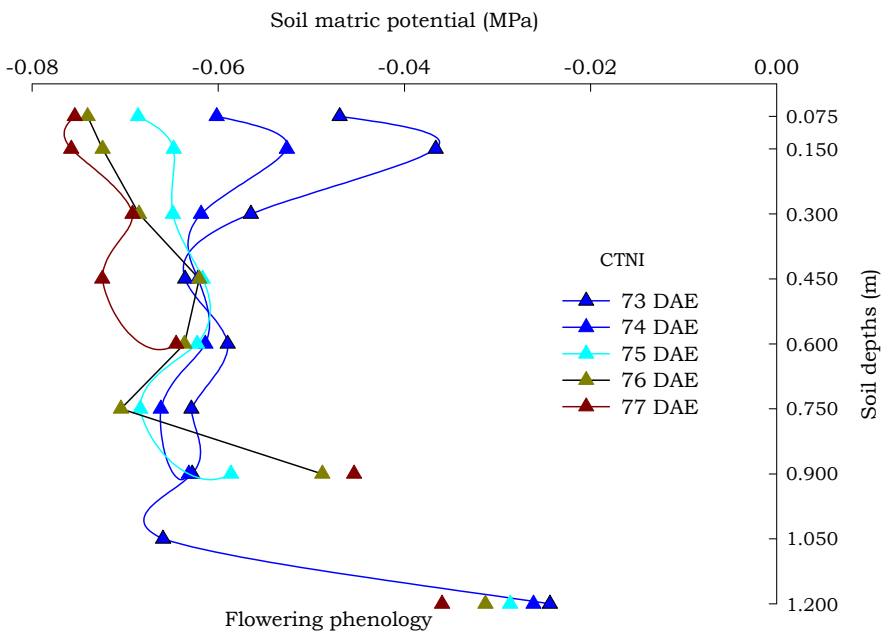

Fig. 4. Soil water matric potential in soybean crops under non-irrigated conventional system (CTNI) from $0.075 \mathrm{~m}$ to $0.30 \mathrm{~m}$ depths, at different days of soil drying, in Eldorado do Sul, Brazil, 2003/04. 


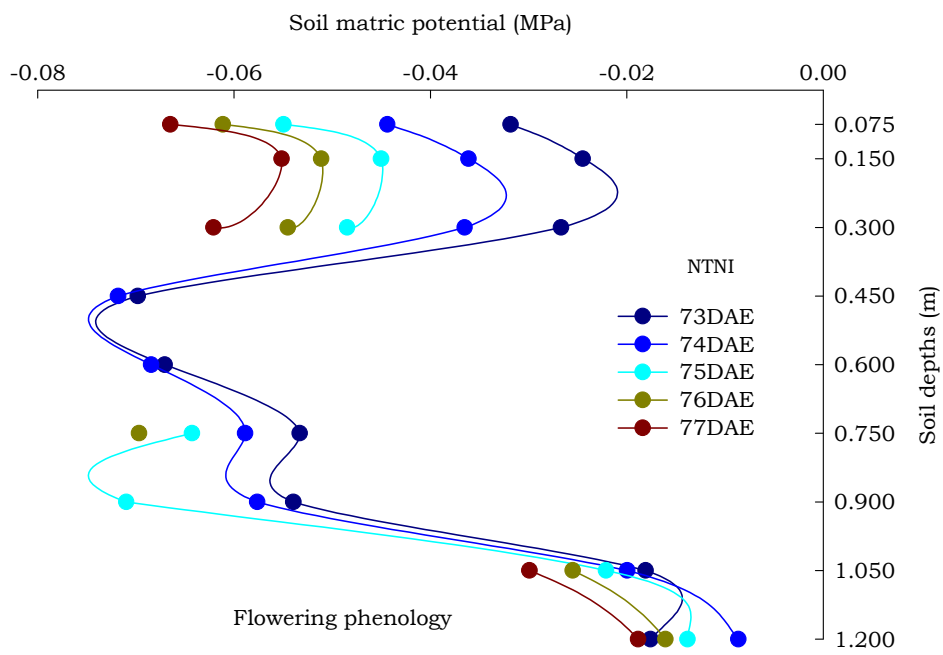

Fig. 5. Soil water matric potential in soybean crops under non-irrigated no-tillage system (NTNI), from $0.075 \mathrm{~m}$ to $0.30 \mathrm{~m}$ depths, at different days after plants emergence, in Eldorado do Sul, Brazil, 2003/04.

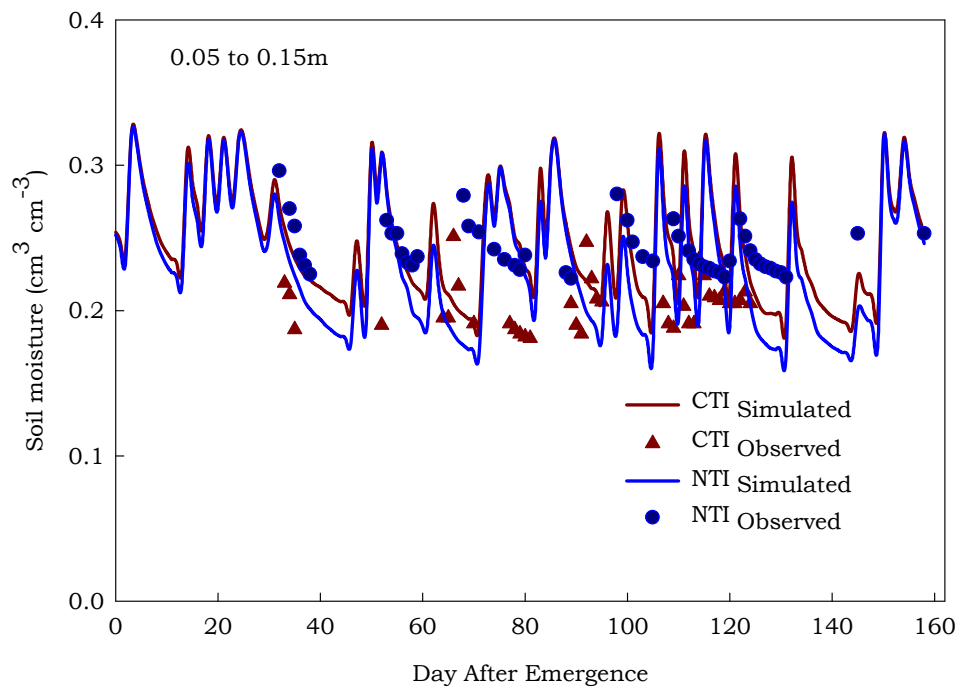

Fig. 6. Observed and simulated volumetric soil moisture at depths of $0.05 \mathrm{~m}$ and $0.15 \mathrm{~m}$, in soybean crops under irrigated conventional tillage (CTI) and irrigated no-tillage (NIT) systems. Eldorado do Sul, Brazil, 2003/04.

In conventional tillage non-irrigated the model's ability was very low (32\%), and no-tillage non-irrigated about $27 \%$ the value for the square root of the mean error, reinforcing the evidence of need for adjustments in routines or subroutines in the model to improve predictions of soil moisture levels. 
According to Martorano et al (2007), the CROPGRO-Soybean was highly efficient in simulating the storage of soil water between $0.15 \mathrm{~m}$ and $0.30 \mathrm{~m}$ in conventional tillage and non-tillage irrigated. It was observed that in irrigated conventional tillage the model had high performance, with minimum distance between the simulated and observed (Fig. 7). The RMSE was $22.4 \%$ and in no-tillage irrigated (NTI) it was about $11 \%$, which was considered a good precision of the model simulating water conditions in both systems adopted by farmers, showing that the tools can be use in management strategies in crops. The D-index of agreement (Willmott et al., 1985) in irrigated non-tillage (NTI) was 0.95, while the irrigated conventional tillage (CTI) had also a high level of agreement, 0.92, indicating high agreement closer to the 1:1 line (Fig. 7).

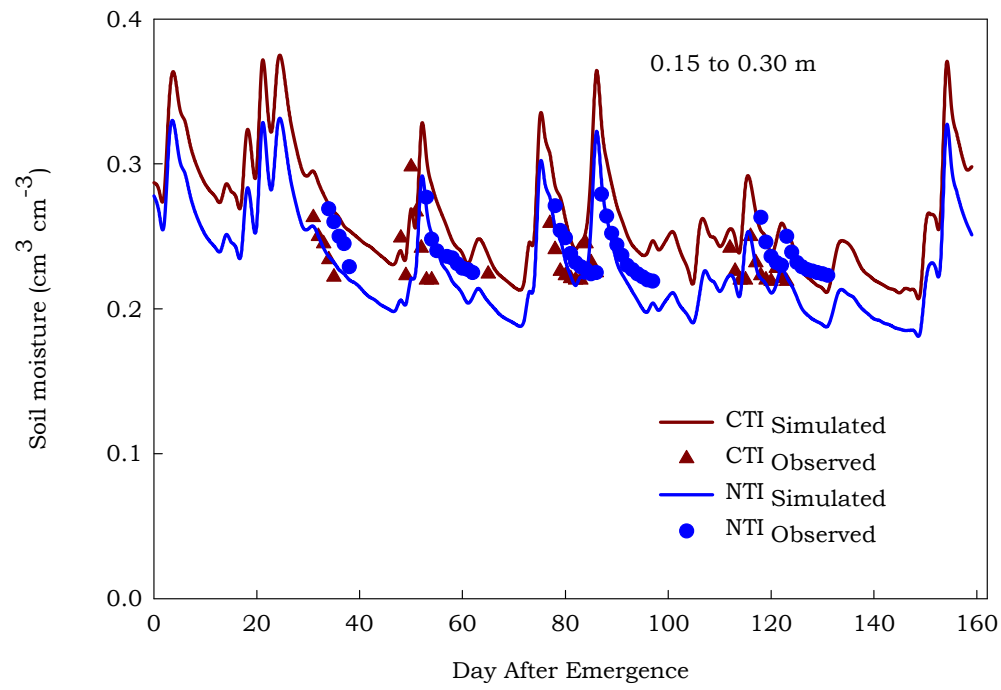

Fig. 7. Simulated soil moisture by CROPGRO-Soybean and observed in the layer between 0.15 and $0.30 \mathrm{~m}$ depths, in irrigated (I) plots of conventional tillage (CT) and no-tillage system (NT). Eldorado do Sul, Brazil, 2003/04.

In the same depth of non-irrigated treatments, the error (RMSE) in CTNI was 24.4\% (which, depending on the boundary condition, may be acceptable) and NTNI was $19.0 \%$ in that limit, indicating good precision and accuracy of model, which can be used to simulate in this layer (Fig. 8). In irrigated conventional tillage the simulated values for the layers of 0.30 and $0.45 \mathrm{~m}$ depth may be considered acceptable presenting a $19.2 \%$ error (RMSE). In irrigated no-tillage it was $22.1 \%$ which, depending on the boundary condition, may be acceptable (Fig. 9).

In assessing the performance of CROPGRO for soybeans, after calibration of parameters such as hydraulic conductivity and root system depth in 224 points in 16 ha, using performance data for three years in Iowa, in the United States of America, Paz et al (1998) found that water stress explained $69 \%$ of income at all points measured, indicating the importance of adjustments in the soil parameters in crop yield simulations. In this sense, to increase the performance of CROPGRO Soybean tillage it is necessary to adjust the 
parameters that simulate the limits of water retention in soil, capable of simulating the water supplies observed in the field, which determine water reserves income grain, in periods of soil drying.

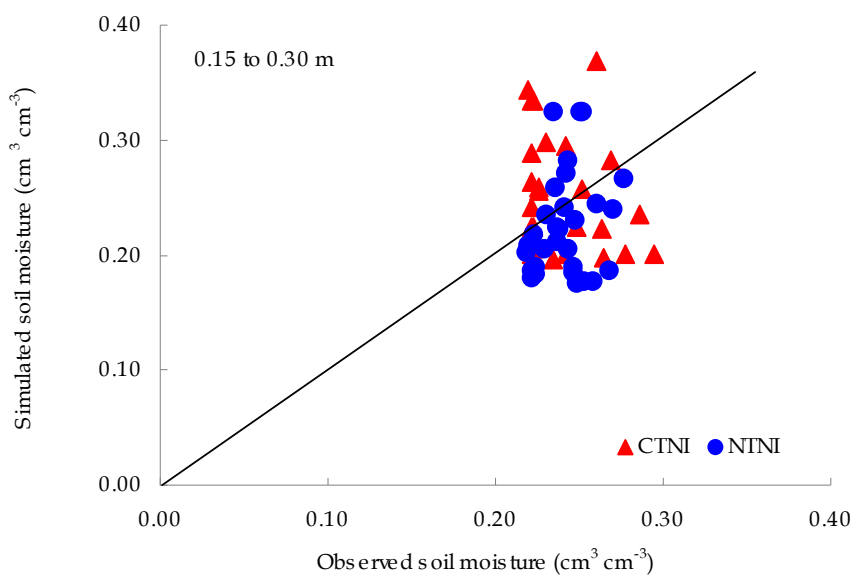

Fig. 8. Simulated soil moisture by CROPGRO Soybean and observed in a field experiment on non-irrigated conventional tillage (CTNI) and non-tillage (NTNI) systems, in the 0.15 to $0.30 \mathrm{~m}$ depths. Eldorado do Sul, Brazil, 2003/04.

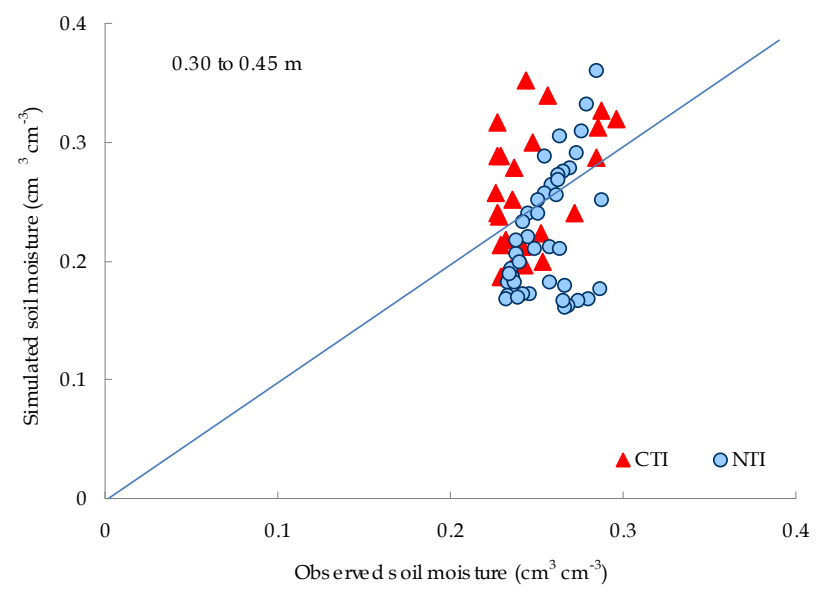

Fig. 9. Simulated soil moisture by CROPGRO Soybean and observed in a field experiment on irrigated conventional tillage (CTI) and non-tillage irrigated (NTI) systems in depths from 0.30 to $0.45 \mathrm{~m}$. Eldorado do Sul, Brazil, 2003/04. 
The model presented better performance in conventional tillage, simulating both the stock of water in the soil for growth and development and yield of soybean, than in the no-tillage system. The model simulations penalize indicators of growth and yield under no-tillage, regardless of the culture water status. The low and middle performance of the CROPGRO Soybean model for simulating the soil water inventories indicates that there is need for adjustments to the parameters that simulate the limits of water retention in soil, capable of simulating moisture observed in the field tillage.

Observing responses in the plant under no-tillage, in terms of growth and yield components, reinforce the effects of the water supply system during periods of dry soil. The comparison between observed and simulated data, through the CROPGROSoybean model, showed high accuracy of the simulated crop phenological stages, as demonstrated by the low scattering of points around the 1:1 line (Fig. 10), mostly for treatments with irrigation. These results may allow an efficient performance of the model in simulating the crop phenology (D-Index $\approx 1$ ) and for estimating the canopy biomass.

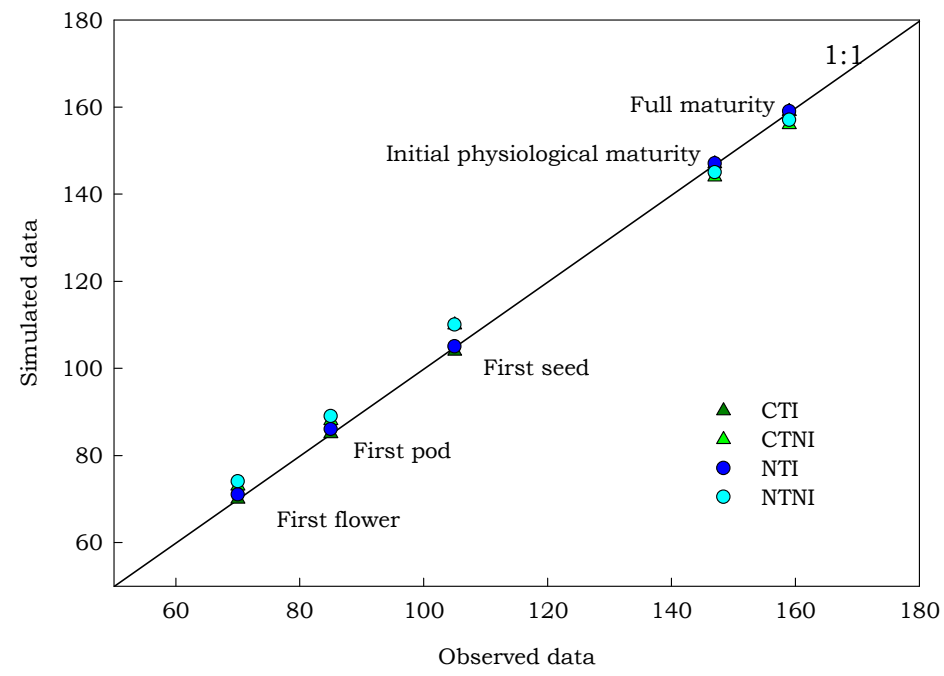

Fig. 10. Simulated by CROPGRO-Soybean model and observed phenological stages (in days after sowing) in CTI (irrigated conventional tillage), CTNI (non-irrigated conventional tillage), NTI (irrigated no-tillage) and NTNI (non-irrigated no-tillage) in Eldorado do Sul, Brazil, 2003/04. 
Plant emergence occurred eight days after sowing (DAS) and the beginning of flower appearance was about 71 days after emergence, with a three-day difference between irrigated and non-irrigated treatments. In conventional tillage with irrigation, the comparison between simulated and observed data showed "D-Index" values corresponding to 0.83 for LAI, 0.96 for plant height, 0.93 for leaf weight, 0.97 for total dry biomass, 0.90 for pod weight and 0.98 for seed weight. In no-tillage system with irrigation, "D-Index" values were $0.82,0.87,0.89,0.94,0.88$ and 0.91 , respectively.

The model had lower accuracy under water deficit (non-irrigated treatments), especially in the no-tillage system. Regarding crop grain yields, the observed data were 3,597 kg ha-1 (irrigated conventional tillage), $3,816 \mathrm{~kg} \mathrm{ha}^{-1}$ (irrigated no-tillage), 1,559 kg ha-1 (nonirrigated conventional tillage) and $1,894 \mathrm{~kg} \mathrm{ha}^{-1}$ (non-irrigated no-tillage). The simulated grain yields by the model were $3,108 \mathrm{~kg} \mathrm{ha}^{-1}$ (irrigated conventional tillage), 2,788 kg ha-1 (irrigated no-tillage), $824 \mathrm{~kg} \mathrm{ha}^{-1}$ (non-irrigated conventional tillage) and $818 \mathrm{~kg} \mathrm{ha}^{-1}$ (nonirrigated no-tillage).

\section{Future research prospective}

In order to increase efficiency of water used by plants, tools like DSSAT have been developed to help farmers with soil crop and water management planning. Researches on this tools applied to field experiments have shown that it is necessary to adjust models capable of simulating available water storage in the soil, especially in no-tilled cropping areas, for increasing the accuracy of simulations of the plant growth and grain yields of soybean by the CROPGRO-Soybean routines for soil water modeling (Faria \& Madramootoo, 1996, Faria \& Bowen, 2003) and soil C sequestration of DSSAT/CENTURY (Tornquist et al, 2009 a e b, Basso et al., 2011).

The models calibrated to deal with the soil system management have great potential to help developing ecologically efficient strategies related to water restitution in the soil, reducing the "Water Footprint" in irrigated tillage, increasing efficiency in food producing (FAO, 2006, FAO, 2009) and reducing agriculture water waste. Agrometeorological assessments help agricultural precision by indicating the right moment for water replacement during the crop phenological stages which are more vulnerable to water stress conditions.

On the other hand, impacts of climate changes related to water cycles, such as occurrence of extreme events and water supply for agriculture, represent major concerns for scientists and stakeholders dealing with environmental, social and economical analysis in different countries around the world. Particularly, the Brazilian economy is closely linked to the supply of natural resources, especially water use, both in agriculture and in hydropower generation, industrial sectors, and human consumption. The lack of adequate water management and planning can cause serious threats to human population. Although, there is plenty of drinking water in many regions of Brazil, this resource may become scarce if there is not any concern about the maintenance of water related ecosystem services. Major world problems occur due to impacts caused by human actions that disrespect the carrying capacity of natural environments.

Awareness of appropriate use by different productive sectors is indispensable to establish sustainable water management in economical activities. Water management should include monitoring and modeling schemes to assess the impact of economical activities on water 
sustainability, for instance, by using the "water footprint" approach to quantify agricultural water use for a particular product (Hoekstra \& Chapagain, 2007). For agriculture, the concerns have turned toward water waste, and not only water scarcity in more arid regions of the world. Waste of water occurs due to improper decisions on water use, such as when, how and what is the most efficient technology to be applied in irrigated crops. Water deficit associated with periods of prolonged drought during the rainy season are a major cause of failed crops of grain in Brazil, especially in states in the Centre-South and Northeast.

Soil C sequestration (Lal, 2004) is reversible, as factors like soil disturbance, vegetation degradation, fire, erosion, nutrients shortage and water deficit may all lead to a rapid loss of soil organic carbon. It's the mechanism responsible for most of the mitigation potential in the agriculture sector, with an overall estimated $89 \%$ possible contribution to the technical potential (IPCC, 2007) excluding, however, the potential for fossil energy substitution through non agricultural use of biomass. There is a paucity of studies integrating soil C sequestration in the GHG balance of pastures and livestock systems (Soussana et al., 2007).

The Intergovernmental Panel on Climate Change (IPCC) pointed out that human actions are contributing to the increase of greenhouse gases (GHGs) in the atmosphere and have stepped up, especially extreme events with serious damage to humanity. Of all global anthropogenic $\mathrm{CO}_{2}$ emissions, less than half accumulate in the atmosphere, where they contribute to global warming. The remainder is sequestered in oceans and terrestrial ecosystems such as forests, grasslands and peatlands (IPCC, 2007).

Considering concerns about climate changes, identification of soil, crop and livestock management to adapt and or mitigate GGE will be focused in new projects, for example, "AN Integration of Mitigation and Adaptation options for sustainable Livestock production under climate CHANGE - Animal Change" and "Role Of Biodiversity In climate change mitigation ROBIN" in the Seventh framework program Food, Agriculture and Fisheries, Biotechnology (FP7). Further information and discussion about Brazilian researches related to livestock emissions of GHG are presented by Perondi et al (2011) and others in the site of "Global Research Alliance on Agricultural Greenhouse Gases (www.globalresearchalliance.org).

\section{Conclusion}

The soil water matric potential showed that drying front is longer in no-tillage system compared to conventional tillage and the CROPGRO-Soybean presented better performance to simulate phenological stages, growth variables and yield components under irrigated conditions than non-irrigated treatments, especially in conventional tillage. Crop yield results for no-tillage system presented low accuracy, mostly for water deficit, as shown by the test of Willmot, suggesting need for adjustment on model parameters to simulate soil water availability, especially for Brazilian agriculture, where no-tillage system area is increasing significantly.

\section{Acknowledgement}

The authors express their thanks to Brazilian Agricultural Research Corporation (Embrapa), the Federal University of Rio Grande do Sul (UFRGS), Institute Agronomic of 
Parana (IAPAR), Foundation Research Agricultural of State Rio Grande do Sul (FEPAGRO) and the National Council for Scientific and Technological Development $\mathrm{CNPq}$ ) for supporting scientific, financial and technological developments in this research. We would like also to thanks UFRGS/Agrometeorology Department to support scientific and friends for its support. The first author would like to thanks the colleagues Azeneth Schuler, Thomas Muello, Daiana Monteiro, Rodrigo Almeida, Leila Lisboa, Siglea Chaves and Salomão Rodrigues for having reviewed this paper.

\section{References}

Allen, D.J. \& Ort, D.R. (2001). Impacts of chilling temperatures on photosynthesis in warmclimate plants. Trends in Plant Science Vol. 6, pp.36-42.

Bergamaschi, H., Guadagnin, M.R., Cardoso, L.S. \& Silva, M.I.G. da. (2003). Clima da Estação Experimental da UFRGS (e Região de Abrangência). Porto Alegre: UFRGS. pp. 78.

Bergamaschi, H., Dalmago, A.G., Bergonci, J.I., Bianchi, C.A.M., Müller, A.G. \& Comiran, F. (2004). Distribuição hídrica no período crítico do milho e produção de grãos. Pesquisa Agropecuária Brasileira Vol. 39, no 9 (Set.), pp. 831-839.

Berlato, M.A. \& Fontana, D.C. (1999). Variabilidade interanual da precipitação pluvial e rendimento da soja no Estado do Rio Grande do Sul. Revista Brasileira de Agrometeorologia Vol. 7, n.1, pp.119-125.

Basso, B., Gargiulo, O. Paustian, K., Robertson, G.P., Porter, C., Grace, P R. \& Jones. J.W. (2011). Procedures for Initializing Soil Organic Carbon Pools in the DSSATCENTURY Model for Agricultural Systems. Soil Science Society of America Journal Vol. 75, Issue: pp. 1 - 69.

Buarque, S. C. (2006). Construindo o Desenvolvimento Local Sustentável: metodologia de planejamento. Ed. Garamond: São Paulo. Brasil. 177p.

Cargnelutti Filho, A., Matzenauer, R. \& Trindade, J. K. da. (2004). Ajustes de funções de distribuição de probabilidade à radiação solar global no Estado do Rio Grande do Sul. Pesquisa Agropecuária Brasileira Vol.39, n.12, pp.1157-1166.

Dalmago, G.A. (2004). Dinâmica da água no solo em cultivos de milho sob plantio direto e preparo convencional. Tese de Doutorado. Porto Alegre: UFRGS, 2004. pp. 244.

Denardin, J.E., Kochhann, R.A., Flores, C.A., Ferreira, T.N. , Cassol, E.A., Mondrado, A. \& Schwarezet, R.A. (2005). Manejo de enchurrada em Sistema Plantio Direto. Porto Alegre. pp. 88.

Dourado Neto, D., Nielsen, D. R., Hopmans, J. W. \& Parlange, M. B. (2005). Soil water retention curve Vol. 1,0, Davis.

FAO (2006). Livestock's Long Shadow-Environmental Issues and Options. Food and Agriculture Organization, Rome, Italy.

FAO (2009). How to feed the world in 2050.

Faria, R. T. \& Madramootoo, C. A., (1996). Simulation of soil moisture profiles for wheat in Brazil. Agric. Water Manage. 31, 35-49. 
Faria, R. T. \& Bowen, W. T. (2003). Evaluation of DSSAT soil-water balance module under cropped and bare soil conditions. Brazilian Archives of Biology and Technology, Curitiba Vol. 46, n. 4, pp.489-498.

Fehr, W.R. \& Caviness, C.E. (1977). Stages of soybean development. Ames: Iowa State University of Science and Technology. pp. 11.

Global Research Alliance (2011). URL: http://www.globalresearchalliance.org/

Hoekstra, A.Y. \& Chapagain, A.K. (2007). Water footprints of nations: Water use by people as a function of their consumption pattern. Water Resources Management Vol. 21, (Oct.), p. 35-48, 0920-4741.

Hoogenboom, G. (2000). Contribution of agrometeorology to the simulation of crop production and its applications. Agricultural and Forest Meteorology Vol. 103, p. 137157.

Hoogenboom, G., Jones, J.W., Poter, C. H., Wilkens, P.W.; Boote, K.J., Batchelor, W. D.; Hunt, L. A. \& Tsuji, G. Y. (2003). Decision Support System for Agrotechnology Transfer (Version 4.0) Vol. 1. Honolulu: University of Hawaii, pp.1-60.

International Consortium for Agricultural Systems Application. (2009). URL: http://www.icasa.net

IPCC (2007). Climate Change 2007. The Physical Science Basis. Contribution of Working Group I to the Fourth Assessment Report of the Intergovernmental Panel on Climate Change. IPCC, Cambridge University Press.

Jones, J.W., Hoogenboom, G., Porter, C.H., Boote, K.J., Batchelor, W.D., Hunt, L.A., Wilkens, P.W., Singh, U., Gijsman, A.J. \& Ritchie, J.T., (2003) The DSSAT cropping system model. European Journal Agronomy Vol. 18 pp. 235-265.

Lal R. (2004). Soil carbon sequestration impacts on global climate change and food security. Science 304, pp. 1623-1627.

Loague, K. \& Green, R.E. (1991). Statistical and graphical methods for evaluating solute transport models: overview and application. Journal of Contaminant Hydrology Vol. 7, pp.51-73.

Major, D.J.; Johnson, D.R. \& Luedders, V.D. (1975). Evaluation of eleven thermal unit methods for predicting soybean development. Crop Science Vol. 15, p.172174.

Martin, T. N.; Storck, L. \& Dourado Neto, D. (2007). Simulação estocástica da radiação fotossinteticamente ativa e da temperatura do ar por diferentes métodos. Pesq. Agropecuária Brasileira [online]Vol. 42, n.9, pp. 1211-1219. ISSN 0100-204X. URL: http://dx.doi.org/10.1590/S0100-204X2007000900001.

Martorano, L.G. (2007). Padrões de resposta da soja a condições hídricas do sistema soloplanta-atmosfera, observados no campo e simulados no sistema de suporte à decisão DSSAT. 2007. pp.151 p. Tese (Doutorado em Fitotecnia/Agrometeorologia), Universidade Federal do Rio Grande do Sul, Porto Alegre.

Martorano, L. G., Faria, R. T., Bergamaschi, H. \& Dalmago, G. A. (2007). Avaliação do desempenho do modelo CROPGRO-Soja para simular a umidade em Argissolo do Rio Grande do Sul. In: Congresso Brasileiro de Agrometeorologia, 15, 2007. Anais Aracaju: SBA, Brasil, pp. 4. 
Martorano, L. G., Faria, R. T. de; Bergamaschi, H. \& Dalmago, G. A. (2008 a). Evaluation of the COPGRO/DSSAT model performance for simulating plant growth and grain yield of soybeans, subjected to no-tillage and conventional systems in the subtropical southern Brazil. Rivista di Agronomia: an international Journal of Agroecosystem Management, vol. 3, n 3 supp. (Jul./Sept.), pp. 795-796, 11254718

Martorano, L.G., Bergamaschi, H., Faria, R.T. de., Dalmago, G.A., Mielniczuk, J.Heckler, B. \& Comiran, F. (2008 b). Simulações no CROPGRO/DSSAT do Carbono no Solo Cultivado com Soja sob Plantio Direto e Preparo Convencional, em Clima Subtropical do Sul do Brasil. Anais da XVII Reunião de Manejo e Conservação de Solo e Água, Rio de Janeiro, Brasil.

Martorano, L.G, Bergamaschi, H., Dalmago, G.A., Faria, R.T. de., Mielniczuk, J. \& Comiran, F. (2009). Indicadores da condição hídrica do solo com soja em plantio direto e preparo convencional. Revista Brasileira de Engenharia Ambiental Vol. 13, nº 4 (Out.), p. 397-405, 1415-4366.

Matzenauer, R., Barni, N.A. \& Maluf, J.R.T. (2003). Estimativa do consumo relativo de água para a cultura da soja no Estado do Rio Grande do Sul. Ciência Rural Vol. 33 (Nov./Dez.), no. 6, pp. 1013-1019, 0103-8478.

Perondi, P. A. O., Pedroso, A. de F., Almeida, R. G. de., Furlan, S., Barioni, L.G., Berndt, A., Oliveira, P. A., Higarashi, M., Moraes, S., Martorano, L., Pereira, L.G.R., Visoli, M., Fasiabem, M. do C. R. \& Fernandes, A. H. B. M. (2011). Emissão de gases nas atividades pecuárias. In: Simposio Internacional sobre gerenciamento de resíduos agropecuários e agroindustriais. Foz do Iguaçu, Paraná, Brasil. pp. 69-73.

Paz, J. O., Batchelor, W. D., Colvin, T. S., Logsdon, S. D., Kaspar, T. C. \& Karlen, D. L. (1998). Analysis of water stress effects causing spatial yield variability in soybeans. Transactions of the American Society of Agricultural Engineers Vol. 41, n.5, pp. 15271534.

Ruiz-Nogueira, B., Boote, K.J.\& Sal, F. (2001). Calibration and use of CROPGRO-Soybean model for improving soybean management under rainfed conditions. Agricultural Systems Vol. 68, Oxon, p. 151-163.

Soussana, J.F.\& Luescher A. (2007). Temperate grasslands and global atmospheric change: a review. Grass and Forage Science Vol. 62, 127-134.

Tornquist, C. G., Giasson, E. ; Mielniczuk, J. ; Cerri, C. E. P. \& Bernoux, M. (2009a). Soil Organic Carbon Stocks of Rio Grande do Sul, Brazil. Soil Science Society of America Journal Vol. 73, p. 975-982.

Tornquist, C. G.; Gassman, P.W.; Mielniczuk, J., Giasson, E. \& Campbell,T. (2009b). Spatially explicit simulations of soil C dynamics in Southern Brazil: Integrating century and GIS with i_entury. Geoderma (Amsterdam) Vol. 150, p. 404-414.

Van Genuchten, M. T. (1980). A closed form equation form prediction the hydraulic conductivity of unsatured soils. Soil Science Society of America Journal Vol. 44: 892898. 
Willmott, C.J., Akleson, G.S., Davis, R.E., Feddema, J.J., Klink, K.M., Legates, D.R., Odonnell, J. \& Rowe, C.M. (1985). Statistics for the evaluation and comparison of models. Journal of Geophysical Research Vol. 90, nº C5 (Sept. 1985), pp. 8995-9005, 0958$305 X$. 


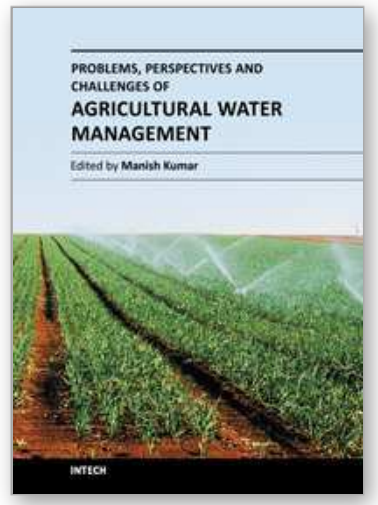

\section{Problems, Perspectives and Challenges of Agricultural Water Management \\ Edited by Dr. Manish Kumar}

ISBN 978-953-51-0117-8

Hard cover, 456 pages

Publisher InTech

Published online 09, March, 2012

Published in print edition March, 2012

Food security emerged as an issue in the first decade of the 21 st Century, questioning the sustainability of the human race, which is inevitably related directly to the agricultural water management that has multifaceted dimensions and requires interdisciplinary expertise in order to be dealt with. The purpose of this book is to bring together and integrate the subject matter that deals with the equity, profitability and irrigation water pricing; modelling, monitoring and assessment techniques; sustainable irrigation development and management, and strategies for irrigation water supply and conservation in a single text. The book is divided into four sections and is intended to be a comprehensive reference for students, professionals and researchers working on various aspects of agricultural water management. The book seeks its impact from the diverse nature of content revealing situations from different continents (Australia, USA, Asia, Europe and Africa). Various case studies have been discussed in the chapters to present a general scenario of the problem, perspective and challenges of irrigation water use.

\section{How to reference}

In order to correctly reference this scholarly work, feel free to copy and paste the following:

Lucieta G. Martorano, Homero Bergamaschi, Rogério T. de Faria and Genei A. Dalmago (2012). Decision Strategies for Soil Water Estimations in Soybean Crops Subjected to No-Tillage and Conventional Systems, in Brazil, Problems, Perspectives and Challenges of Agricultural Water Management, Dr. Manish Kumar (Ed.), ISBN: 978-953-51-0117-8, InTech, Available from: http://www.intechopen.com/books/problems-perspectivesand-challenges-of-agricultural-water-management/decision-strategies-of-soil-water-substitutio-in-soybeansubjected-to-no-tilleage-and-conventional-s

\section{INTECH}

open science | open minds

\section{InTech Europe}

University Campus STeP Ri

Slavka Krautzeka 83/A

51000 Rijeka, Croatia

Phone: +385 (51) 770447

Fax: +385 (51) 686166

www.intechopen.com
InTech China

Unit 405, Office Block, Hotel Equatorial Shanghai

No.65, Yan An Road (West), Shanghai, 200040, China

中国上海市延安西路 65 号上海国际贵都大饭店办公楼 405 单元

Phone: +86-21-62489820

Fax: $+86-21-62489821$ 
(C) 2012 The Author(s). Licensee IntechOpen. This is an open access article distributed under the terms of the Creative Commons Attribution 3.0 License, which permits unrestricted use, distribution, and reproduction in any medium, provided the original work is properly cited. 